\title{
Структура исторической колеи России: проблемы методологии
}

\author{
В.И. ИЛЬИН*
}

\begin{abstract}
*Владимир Иванович Ильин - доктор социологических наук, профессор, СанктПетербургский государственный университет, Сыктывкарский государственный университет; ассоциированный сотрудник, Социологический институт РАН. Адрес: 199034, Санкт-Петербург, Университетская наб., д. 7-9. E-mail: ivi-2002@yandex.ru
\end{abstract}

Цитирование: Ильин В.И. (2017) Структура исторической колеи России: проблемы методологии // Мир России. Т. 26. № 4. C. 30-50. DOI: 10.17323/1811-038X-2017-26-4-30-50

Целью данной статьи, продолжающей размьлиления на темы, которые обсуждаются в монографиях «Россия как циивилзащия» и «Нова ли новая Россия?», является попьтка уточнить категориальный аппарат, позволяющий интегрировать цчивилизационный подход и концепциии социальной инерциии (зависимости от прошлого пути - path dependency). Цивилизащионный подход, возникнув в рамках философии истории, в силу масштаба предмета не склонен вглядываться в эмпирические детали. Сейчас он все активнее проникает в историю, экономику и соииологию. Однако сдвиг в предметном поле не подкрепляется разработкой адекватной этим конкретным наукам методологии. В условиях нехватки эмпирических аргументов, высттроенньх в соответствии с принципами научной методологии, вопрос о месте России в системе локальных ичивилизаций по-прежнему остается предметом веры, поскольку ни одна из спорящцих сторон не может привести аргументы, представляющиеся оппонентам убедительными. Главным недостатком существующих исследований данной проблемы остается акиент на методах сравнения, часто допускающих синхронное сравнение стран, находящихся на разных этапах развития одного и того же типа общества, использование произвольно подобранных аналогий, что отвечает логике дедукции, когда факты собираются для иллюстрации теоретической концепции. Неудивительно, что проблематика ичивилизационного анализа России, несмотря на полуторавековую историю, больше интегрирована в идеологический, чем научньй дискурс. Концепџии социальной инеричии, возникшие в экономических науках, гораздо более точны и конкретны, но именно в силу этих достоинств они с трудом применимы для тысячелетнего диапазона.

В статье предлагаются две группь категорий, которые могут стать неким шагом вперед на пути сближения цุивилизащионного подхода и конщепций зависимости от проилого пути. Первая группа категорий позволяет анализировать механизмы исторической преемственности периодов одной цุивилизации: (1) цุивилизаџионный стержень как сово- 
купность факторов, действующих на протяжении всей истории; (2) историческая колея как реальные формы реакций на них, создающие фундамент для последующих периодов; (3) цчивилизационные ловушки как щаги (часто политические), приобретшие необратимые последствия для будущего. Вторая группа категорий-это разные типь колеи, пронизьваюшие многовековую историю: географическая, геополитическая, политическая, колея собственности, религиозная, ментальная и колея исторической памяти. Данная категориальная сетка дает возможность упорядочить эмпирическую проверку гипотез ијивилизаџионного анализа относительно многовековой преемственности.

Ключевые слова: цивилизационный подход, социальная инерция (зависимость от прошлого пути), цивилизационный стержень, цивилизационная колея, цивилизационные ловушки, социальные ресурсы, географический и геополитические факторы, православие, менталитет, историческая память

\section{Введение}

Цивилизационный подход возник в рамках философии истории, опираясь на присущую ей методологию, нечувствительную к эмпирическим деталям [Данилевский 1991; Тойнби 1991], при этом рост популярности этого подхода привел к попыткам использования его и в истории. Наиболее заметным достижением в этом направлении стали труды Ф. Броделя, однако масштаб исследования требовал обобщений, которые под силу только философии и истории. В «Грамматике цивилизаций» уровень резюмирования оказался настолько значительным, что Ф. Бродель вынужден был уйти от методологии исторической науки в сторону философии истории [Бродель 2008]. Правда, жанр учебника для лицеев стал важным дополнительным фактором, и в других (собственно исторических) трудах Ф. Бродель, не отказываясь от категории цивилизации, сузил рамки предмета и в пространстве, и во времени, одновременно отойдя от ключевых вопросов цивилизационного анализа, связанных с классификацией путей исторического развития народов [Бродель 1992]. Однако далеко не все обобщающие исторические труды имеют отношение к цивилизационному анализу ввиду отсутствия в них соответствующих исследовательских вопросов (например, фундаментальные труды по российской истории Б.Н. Миронова [Миронов 2003; Миронов 2009]).

С конца 1990-х гг. наблюдается рост интереса к цивилизационному анализу и в сфере исторической социологии (см. [Браславский 2010; Масловский 2012]). Большую роль в появлении цивилизационного поворота в российской социологии сыграл междисциплинарный московский научный семинар «Типы цивилизаций и характер социально-экономического развития», организованный в 2009 г. О.И. Шкаратаном на площадке Национального исследовательского университета «Высшая школа экономики» при содействии Лаборатории сравнительного анализа развития постсоциалистических обществ. Итогом этой работы стала серия статей и коллективных монографий, которые заметно актуализировали полуторавековой спор «Россия - это Европа?» [Шкаратан, Лексин, Ястребов 2015; Шкаратан, Ястребов 2016]. В фокусе внимания этой исследовательской группы стоит в первую очередь вопрос о влиянии цивилизационного фактора на постком- 
мунистические трансформации [Шкаратан 2008]. Попыткой перехода от философии к макросоциологии является и фундаментальный труд Н.С. Розова «Колея и перевал. Макросоциологические основания стратегий России в XXI веке» [Розов 2011]. Примыкают к цивилизационному анализу исследования в области институциональной экономической истории О.Э. Бессоновой и С.Г. Кирдиной [Бессонова 2006; Бессонова 2015; Кирдина 2000]. Предложенная вниманию читателей статья является логическим продолжением этой дискуссии.

Цивилизационный анализ решает две основные группы проблем. Во-первых, это вопрос границы между локальными цивилизациями, которому посвящено большинство исследований, проведенных в рамках данной традиции (пространственный ракурс). Во-вторых, это проблема исторической цельности локальной цивилизации, т.е. встает вопрос о том, как предшествующие периоды истории одной и той же цивилизации предопределяют логику последующих периодов. Если общий цивилизационный стержень отсутствует, то данная цивилизация как научный конструкт распадается. Как писал Ф. Бродель, «человек живет преимущественно в рамках собственного опыта и по мере движения поколений оказывается в ловушке своих прежних достижений. Человек-то есть группа, к которой он принадлежит: одни индивиды ее покидают, другие включаются в нее, но группа остается привязанной к данному пространству, к знакомым ей землям. Она в них вросла корнями» [Бродель 1992].

Проблема исторической преемственности в цивилизационном анализе России пока разработана гораздо слабее, чем тема отличий российской (евразийской) и западной цивилизаций. Основными методологическими инструментами исторического аспекта цивилизационного анализа являются сравнение, аналогии, а также дедукция как избирательное упорядочивание фактов с целью обоснования уже существующей концепции. При переходе из философии в предметное поле наук, тяготеющих к строгому эмпирическому обоснованию, данный инструментарий не обеспечивает достаточной убедительности, открывая возможности для сосуществования не менее аргументированных противоположных концепций (например, модернизации). Такая система доказательств не убеждает оппонентов. В результате одни верят в одно, другие - в другое. Выход из этой ситуации, нормальный для идеологических и философских споров, но неприемлемый для науки, выводы которой не могут быть привязаны к вере в те или иные ценности, может находиться в сфере интеграции цивилизационного анализа и концепций социальной инерции (зависимости от прошлого пути - path dependency).

В отличие от цивилизационного подхода, эти концепции возникли в рамках не философии истории, а в лоне экономических наук, которые всегда негативно относились к философскому полету мысли на высотах, с которых разглядеть эмпирические аргументы не представляется возможным. Методология социальной инерции стремится объяснить в терминах причинно-следственной связи динамику преимущественно соседствующих во времени фаз развития обществ, институтов или индивидов, и этот подход ориентируется на выявление конкретных институциональных механизмов, обеспечивающих преемственность. Применительно к России и другим постсоциалистическим странам на первый план выходит вопрос, как социальные институты советского времени сохранились на новом этапе исторического развития, где в прежней форме их быть уже не должно. Однако эти во- 
просы уходят и в более ранние эпохи, поскольку у советских институтов также были давние исторические корни.

Частичное переплетение предметов цивилизационного подхода и концепций социальной инерции подводит к теме о возможности их интеграции, однако их механическое соединение представляется бесперспективным в силу разных масштабов предметов и вытекающих отсюда методов анализа. Для их интеграции необходима разработка методологических мостов, сближающих эти подходы. Удачным примером интеграции является монография Р.М. Нуриева и Ю.В. Латова «Россия и Европа: эффект колеи (опыт институционального анализа истории экономического развития)» [Нуриев, Латов 2010]. Правда, в фокусе внимания этих авторов стоит вопрос не пронизывающей века преемственности, а институциональных развилок, на которых пути России и Западной Европы расходились, и принимавшиеся когда-то стратегические решения оказывались ловушками, из которых потомки выбраться не смогли. Ипполит Тэн в своем труде «Происхождение современной Франции», пожалуй, первым попробовал предложить научно обоснованный баланс Великой французской революции, когда пороки старого порядка были ликвидированы ценой огромных жертв, а на смену мягкому абсолютизму пришли новые, гораздо более жестокие формы деспотизма [Тэн 1907].

Целью данной статьи является определение возможных направлений использования концепций социальной инерции (зависимости от прошлого пути) как инструмента проверки гипотез цивилизационного анализа.

\section{Структура механизма зависимости от прошлого пути}

Каковы же элементы механизма институциональной преемственности исторических эпох? Во-первых, это цивилизационный (ресурсный) стержень, выступающий как совокупность ресурсов, которые на протяжении веков оказывают серьезное влияние на формирование институциональных форм. Ассортимент ресурсов, использование которых формирует историю народа, включает в себя географическое положение (в терминах физической и политической географии), климатические условия, природные ресурсы, материальную культуру, систему управления, духовную культуру, язык, менталитет и т.д. Категория стержня заостряет внимание на исторически сквозном характере ресурсов, привязанных не к историческому периоду, а к территории. Цивилизационный стержень как будто нанизывает эпохи на себя. Различия между цивилизациями проявляются именно в разных стержнях, пронизывающих многовековую историю. С одной стороны, ресурсы дают шансы для тех или иных практик, с другой, ограничивают их. В каждый исторический момент цивилизационный стержень представляет собой набор возможностей, из которых лишь некоторые становятся реальностью, иначе говоря, между ним и историей народа отсутствует жесткая причинно-следственная связь. Влияние этого стержня носит многовекторный характер: на каждой из исторических развилок развитие может пойти не тем путем, который был выбран, а тем, который был возможен, и в одних и тех же объективных условиях разные народы нередко отдают предпочтения отличным друг от друга путям. 
Ресурсный стержень представляет собой набор объективных возможностей, реализация которых зависит от социальных субъектов - от осознания ими своих потребностей, от иерархии выдвигаемых целей, от наличия знаний и навыков использования данных ресурсов. В силу этого одни и те же ресурсы могут иметь принципиально разное значение в различных исторических условиях: например, нефтяные залежи никак не влияют на хозяйственную жизнь, если отсутствуют двигатели внутреннего сгорания и техника, позволяющая извлекать нефть из недр земли. Несмотря на принципиальную важность климатических условий для сельского хозяйства, в условиях индустриальной и постиндустриальной экономики их роль радикально снижается.

Вторым элементом механизма институциональной преемственности является историческая колея народа как разновидность траектории его движения, описывающая использованные и упущенные возможности. В ней интегрируются объективные структуры и деятельность в их контексте. Данная категория акцентирует внимание на зависимости настоящего от прошлого, на связи разных исторических эпох.

Она включает в себя только те ресурсы, которые были использованы на каждом этапе и только в тех формах, которые были применены. Обратной стороной этого процесса являются упущенные шансы, не использованные ресурсы (колея упущенных возможностей). У каждой цивилизации свой набор возможностей, которые не были реализованы. Характеристики колеи содержат ее направление и конкретные формы практик, с помощью которых шло движение в этом направлении. Иными словами, материалом колеи являются освоенные ресурсы и устойчивые практики их использования, и то, что не было задействовано, остается в запасниках упущенных или отвергнутых шансов. О них можно говорить, сетовать, но они уже не оказывают заметного влияния на развитие общества.

Селективная природа ресурсов, формирующих колею, предопределяет ее программирующий характер: она дает возможности, которые обеспечены освоенными ресурсами, и отсекает те, которые недоступны. Поскольку будущее начинается со стартовой площадки сегодняшних возможностей, то историческая колея это не только прошлое, но и принуждение к соответствующей логике будущего. Люди творят свою историю, используя доступные и освоенные ими ресурсы, и разные народы формируют собственные наборы даже в одинаковых объективных условиях.

Третьим элементом механизма институциональной преемственности являются цивилизационные ловушки. История - это длинная череда принципиальных и второстепенных развилок, она состоит из цепочки ситуаций стратегических и тактических выборов народа (очень часто этот выбор от его имени делают властвующие субъекты), и почти в каждой точке подобного рода есть возможность «пойти налево или направо». Категория ловушки подчеркивает необратимый характер выбора: назад либо не вернуться, либо это будет видимость возврата в силу необратимости исторического процесса (например, создание свободного рынка в эпоху, выдвинувшую на первый план проблему обуздания его стихии). Поэтому выборы, совершавшиеся в прошлом, являются важными элементами механизмов, программирующих настоящее и будущее. Характер нынешней колеи во многом сформирован предками, это то, что в экономической истории называют «институциональными ловушками» (или lock-in - блокировками), под которыми понима- 
ются неэффективные, но устойчивые нормы поведения [Полтерович 1999, с. 11], а эффективный с точки зрения тактики путь может оказаться тупиком или поражением в контексте долгосрочной стратегии. Однако такие ловушки не ограничены сферой экономических институтов: они встречаются во всех областях общественной и личной жизни. Иногда такие ловушки, в которых был явный тактический успех конкретного момента, оказываются началом неэффективного или даже тупикового пути длиной в столетия.

Один из наиболее распространенных вариантов попадания в ловушку война, которую развязывает правительство, ставя народ перед фактом дилеммы в духе «родина или смерть!» Сакральность выбора, отодвигающего на периферию рациональность, программирует его исход. Потом начинает действовать колея войны и преодоления ее последствий, выйти из которой чрезвычайно трудно. Такая колея обычно предполагает глубокую реконфигурацию всех структур общества во имя победы: в 1914 г. для участия в войне с Германией у народа России не было никаких причин, тем не менее правительство вступило в войну во имя целей, которые очень быстро были забыты, однако возникла колея, которая вполне логично вела к революции, Гражданской войне и большевистской диктатуре на многие десятилетия. Так шаг, сделанный правящей элитой, стал причиной реконфигурации цивилизационной колеи.

Когда на развилке сделан выбор, движение идет по избранному пути. В него вкладываются ресурсы (зачастую колоссальные), в том числе и время, и когда обнаруживается, что выбор был не самый лучший, изменение направления развития государства возможно только ценой огромных потерь, обусловленных логикой «Интернационала» - «Весь мир насилья мы разрушим/ До основанья, а затем/ Мы наш, мы новый мир построим...». Возможно, что новый мир будет лучше старого, но какой ценой? Наиболее яркий пример такого поворота - революции, ущерб от которых далеко не всегда компенсируется возможностями расчистки институциональных блокировок старого режима. Ипполит Тэн первым дал фундаментально обоснованный ответ на этот вопрос применительно к Великой французской революции [Тэн 1907], это же подтвердила и русская революция 1917 г. Принимая во внимание, что радикальные реформы чреваты серьезными потерями, властвующие элиты нередко продолжают следовать неэффективным путем, полагая, что смена курса обойдется еще дороже, и, в итоге, потомки часто идут дорогами, выбранными предками. Это одна из объективных основ консервативного сознания.

\section{Географическая колея}

Преемственность институционального развития в существенной мере обусловлена относительной неизменностью географического положения страны или группы стран. Как писал Ф. Бродель, «каждая цивилизация привязана к какому-то географическому пространству, границы которого более или менее стабильны. Отсюда вытекает, что каждая цивилизация имеет особую, свойственную именно ей географию, предполагающую совокупность возможностей, трудностей, некоторые из которых носят перманентный характер» [Бродель 2008, с. 41]. Данный фактор всегда был в центре внимания и российских историков, стремившихся объяснить 
особенности развития нашей страны. Это цивилизационный стержень, как комплекс ресурсов, открывающих одни возможности и закрывающий другие, причем его воздействие носит многовекторный характер.

Географическое положение влияет, преломляясь через призму культуры и политических устремлений государства: например, многие реки, некогда игравшие системообразующую роль в процессах размещения населения, определении конфигурации потоков материальных ресурсов и т.д., в настоящее время выполняют в основном пейзажную функцию. Аналогичным образом природно-климатические условия, будучи объективно относительно неизменными, радикально меняют свою роль в качестве фактора исторического развития. Кроме того, в связи со сдвигом ареала расселения в южные регионы Восточной Европы (начало XIXв.) значение климата в исторических землях России упало даже для развития сельского хозяйства страны.

Помимо этого, территориальные масштабы России, веками выступавшие ключевым фактором ее истории, утратили прежнюю значимость в результате произошедшей в средствах коммуникации революции. В современном мире доступность измеряется не километрами, а наличием и добротностью дорог, маршрутами авиаперевозок, качеством транспортных средств, платежеспособностью населения. И когда мы начинаем вглядываться в изменения смысла географической константы, становятся заметны ограничения цивилизационного анализа, поскольку цивилизационный стержень географического положения, проходя через века, постепенно меняет свои смыслы. Путь от Москвы до Владивостока на телеге и на «Боинге» - это существенно разные характеристики освоенного физического пространства. Географическая колея - это не объективное положение страны, а исторически меняющиеся способы его использования (т.е. синтез структуры и практики), и в отличие от цивилизационного стержня географическая колея приобретает противоречивый и неустойчивый характер.

\section{Колея территориальной экспансии}

Огромные масштабы российской территории не являются кем-то (богом, судьбой, природой) данным фактором. Это материализация национальной энергии, веками принимавшей форму борьбы за территорию - за ее расширение, улучшение геополитической конфигурации и удержание. Эта борьба, принимая форму колеи, проходит через всю русскую историю, начиная с эпохи Древней Руси и заканчивая современностью. Территориальная экспансия (иной, более позитивный термин, распространенный в российской историографии, - «собирание земель») оказала огромное влияние на все социальные институты страны.

Стремление к территориальной экспансии не было уникальной чертой русского государства и народа. К этому на многих этапах истории стремились все, но мало кому это удавалось. Пересмотр отношения к территориальной экспансии обозначился лишь во второй половине $\mathrm{XX}$ в.: развал колониальных империй стал следствием не только и, вероятно, не столько национально-освободительной борьбы, сколько осознания элитами метрополий, что поддержание империй чревато слишком большими издержками, а экономические выгоды проще получать через 
институты неоколониализма и глобализации. В ХХ в. США убедительно показали преимущества именно этой стратегии, оказавшейся привлекательной и для колониальных империй Европы. Возможно, и развал СССР в существенной мере связан с изменением геополитической логики российских элит, начавших склоняться к новой форме экспансии с помощью рычагов «мягкой силы».

Особенностью российской территориальной экспансии на протяжении всей ее истории была второстепенная роль экономических интересов. Как верно отмечает Б.Н. Миронов, правящие верхи в первую очередь стимулировали «... геополитические соображения: обеспечить прочные границы, обрести незамерзающие порты, воспрепятствовать захвату пограничных территорий соперниками или включить их в сферу своего влияния» [Миронов 2003, т. 1, с. 26-27]. Идеологическим обоснованием такой экспансии нередко в явной или скрытой форме была идея «собирания земель», некогда входивших в Киевскую Русь и Золотую Орду, преемницей которых и выступила Россия.

Из этой колеи сложно было выйти. При этом цепная реакция серьезно затрагивала и социальный порядок страны. Как писал С.М. Соловьев, российское государство обладало громадной областью и малым населением. Выходом из этого противоречия было принуждение к военной службе [Соловьев 1996, т. 18, с. 21 ]. Этот тезис можно переформулировать и так: огромная диспропорция населения и территории, которую надо охранять, активизировала тенденцию к милитаризации социального порядка, что негативно сказывалось на хозяйственном развитии. И эта диспропорция, как рок, проходит через всю русскую историю.

\section{Колея великой державы}

Колея великой державы, обладающей неограниченным суверенитетом, относительна и неустойчива. До Второй мировой войны в этот клуб входили Германия, Франция, Великобритания, Япония, что проявлялось в их способности выстраивать свою внутреннюю политику без оглядки на другие страны. Оккупация в 1945 г. Германии и Японии существенно ограничила влияние институциональной логики их собственного прошлого на настоящее. На это были направлены масштабные и глубокие преобразования, начатые оккупационными властями и продолженные национальными органами власти (принудительные денацификация, демилитаризация, демократизация и т.д.). Существенно изменилась роль в мире Великобритании и Франции. И в настоящее время национальный суверенитет некогда великих держав с независимой внешней политикой несколько ограничен в обмен на гарантии безопасности, предоставляемые Соединенными Штатами, которые несут основное бремя военных расходов и осуществления стратегии «мягкой силы» и концентрируют в своих руках ключевые технологические и экономические ресурсы мира. Кроме того, эти государства входят в международные союзы, оказывающие мощное влияние на формирование современного отрезка их колеи. В результате и по сей день ключ к пониманию ряда важных процессов в их жизни лежит за пределами собственных границ.

Россия в 1990-е гг. пыталась включиться в клуб ведущих государств, следующих в фарватере американской политики, но в силу разных причин, анализ 
которых выходит за пределы темы данной статьи, эта попытка была неудачной. Это не означает, что такой путь не являлся объективно возможным. Кремль вернулся в колею суверенной геополитики, взяв на себя одновременно и тяготы ее обеспечения, и сопутствующие ей риски конкуренции с несравненно более сильными соперниками. Особенностью нашей истории является то, что Россия всегда несла бремя великой державы, являясь экономически наименее развитым членом этого клуба. Такая статусная рассогласованность оказывает глубокое воздействие на все сферы внутренней жизни страны.

Суть исторической колеи малых государств за редким исключением состоит в принадлежности к той или иной империи или зоне ее влияния. Их внутреннее развитие всегда определялось в первую очередь не их национальной культурой, а тем, в какую империю они входили. Культура же выполняла роль фильтра, который придавал специфику имперскому влиянию, оставлявшему свободу выбора, в основном, на уровне частной жизни и общинных форм самоорганизации. Именно империя предопределяла формы управления и хозяйственной жизни, проводила или откладывала реформы, подавляла одни особенности местной культуры и поощряла другие. В силу этого кажется необоснованным выведение О.И. Шкаратаном стран Балтии за пределы этакратической логики [Шкаратан, Ястребов 2016, с. 92]. Даже их исторически непродолжительная независимость всегда сочеталась с вынужденным ограничением национального суверенитета. Как верно отмечает Д. Лейн, «... членство в ЕС предполагает подчинение национального суверенитета общеевропейской экономической, политической и социальной политике, которую в целом можно охарактеризовать как основанную на неолиберальных принципах. $<\ldots>$ По иронии судьбы, войдя в ЕС после долгожданного избавления от советской гегемонии, страны Центральной и Восточной Европы на самом деле частично лишились вновь обретенной независимости, поскольку автономность их внешней и внутренней политики отныне была ограничена условиями членства в новом объединении. Более того, юридически и политически эти страны перестали быть суверенными государствами, превратившись в государства-члены ЕС» [Шкаратан, Ястребов 2016, с. 55]. Аналогичным фактором формирования новой фазы колеи является и членство в HATO.

Колея великой державы не является роком, предопределенным имеющимися ресурсами (территория, население, природные ископаемые): ресурсы открывают возможности, но воспользоваться ими могут лишь правящие круги, обладающие великодержавными амбициями. Иначе говоря, возможность - это еще не действительность.

\section{Геополитическая колея}

Геополитическая идентичность государства - это синтез амбиций его правящих кругов и отношения к нему значимых стран. Даже самые мощные державы мира в той или иной мере формировали свою геополитику в реактивном формате. В силу своего географического положения и имеющихся разнообразных ресурсов российская территория периодически выступала объектом геополитики 
соседних государств. В одних случаях это были попытки прямого завоевания (нашествия татаро-монголов в XIII в., французов - в 1812 г., нацистов и их союзников - в 1941 г.). Однако гораздо чаще правящие круги России сталкивались со стремлением соседних государств ограничить ее влияние как независимого игрока на международной арене. Такие внешние факторы создавали геополитическую колею России, правящие круги которой всегда стремились обезопасить свою территорию, что нередко понималось в терминах ее расширения с целью улучшения стратегического положения (например, войны за выход к морям, удаление границы от столицы), а также поддержания и усиления своего влияния на другие страны.

Кремль в 1990-е гг., приняв неолиберальную идеологию и взяв курс на интеграцию с западным миром, столкнулся не только с явным нежеланием принимать туда Россию, но и с политикой ее военного сдерживания «на всякий случай». Т.Ю. Сидорина, анализируя дифференциацию трансформационных путей, совершенно верно обращает внимание на фактор политики западных стран, которые после развала советского блока и СССР отказались от строительства «общеевропейского дома» и взяли курс на усиление институтов, сформировавшихся в контексте холодной войны, - НАТО и Европейского союза, на их расширение на восток [Шкаратан, Ястребов 2016, с. 54-56]. Принятие ряда бывших советских республик в НАТО, а затем и подготовка развертывания ПРО в Европе - шаги, направленные на сдерживание России под предлогом защиты Европы от несуществующих иранских ракет. Таким образом, именно НАТО выступило инициатором конструирования уже новой России как опасного государства, с которым надо разговаривать с позиции силы. В данной ситуации срабатывает механизм стигматизации, которая, являясь инструментом профилактики потенциальных опасностей, в реальности запускает самореализующиеся пророчества. Западный мир ждал от России ее возврата к политике реставрации статуса великой державы, причем эти ожидания были настолько реалистичны, что подготовили Кремль к этому повороту.

Мюнхенская речь В.В. Путина стала открытым отказом Кремля от подыгрывания этой политике. «Для современного мира, - заявил российский президент, - однополярная модель не только неприемлема, но и вообще невозможна» [Путин 2007]. Так Россия постепенно, но вполне открыто начала возврат к старой схеме конструирования себя в качестве одного из глобальных полюсов, а логика геополитического вектора «стран победителей» в холодной войне запустила этот процесс в глобальном масштабе. Активные действия Кремля в конфликтах с Грузией (2008г.) и Украиной (с 2014 г.) уже не меняли траекторию движения по исторически сложившейся геополитической колее, а лишь обострили ее формы.

Из следования в этом геополитическом направлении закономерно вытекает политика внутренней мобилизации, и традиции подсказывают проверенный веками путь формирования и поддержания авторитарного режима той или иной степени жесткости. Эта же логика геополитической колеи толкает к принятию мер по ограничению влияния в стране потенциальных геополитических противников с целью формирования относительно независимой от внешних угроз экономической системы и минимизации рисков глобализации и санкций других государств. 


\section{Колея власти-собственности}

Геополитическая ситуация и прямо, и косвенно создает силовое поле, трансформирующее внутренние процессы. Эта логика конвертации внешнего во внутреннее уходит в глубь веков. «Все формы государственного монополизма производны от главной монополии - монополии Русского государства на защиту» [Нуреева, Латов 2010, с. 67]. Внешняя опасность становится универсальным фактором, благоприятствующим формированию феномена власти-собственности. При этом совершенно неважно, является ли опасность реальной или мнимой, придуманной властью по ошибке или из-за корысти. Перефразируя «теорему Томаса», можно утверждать, что угрозы, которые воспринимаются как настоящие, реальны по своим последствиям.

В период татаро-монгольского господства (1240-1462 гг.) военные столкновения в русских землях случались почти ежегодно (200 войн за 222 года); в 1368-1893 гг. в среднем на два года войны приходился один мирный год. Все это было тесно связано со структурой государственных расходов: в доимперскую эпоху доля прямых военных расходов колебалась в интервале 50-90\% государственного бюджета, в имперскую - редко опускалась ниже 30\% [Шкаратан, Лексин, Ястребов 2015, с. 114]. Во времена СССР эта традиция сохранилась. Правда, эти цифры демонстрируют и динамику изменений функций государства, отражающуюся в структуре его бюджета.

Однако сама по себе угроза извне автоматически не порождает властьсобственность, поскольку возможность не конвертируется непосредственно в действительность. В Западной Европе было не меньше внешних угроз, тем не менее они чаще всего порождали иные сценарии институционального развития, разные типы колеи. Кроме того, и в русских землях существовали отличные от традиционных варианты институциональной колеи, апробированные в Новгородской боярской республике, Великом княжестве литовском и казацких землях.

Власть-собственность вполне обоснованно сформировала специфическую систему распределения - раздаточное хозяйство [Бессонова 2006; Бессонова 2015]. Эта система распоряжения собственностью создавала ранее и создает до сих пор социальную структуру, ядром которой является иерархия сословного типа [Кордонский 2008], а раздаточные институты и сословная система становятся ресурсами, обеспечивающими возможность государства мобилизовать силы на важных для него направлениях в условиях дефицита рыночных регуляторов и формируемых ими стимулов. Этот путь был выбором одной из возможных альтернатив.

И тут встает важный методологический вопрос: является ли средневековая ситуация причиной неумолимого тренда современной России к воспроизводству власти-собственности. Видимо, нет. Эта система воспроизводилась веками в результате непрерывного повторения внешних угроз, которые интерпретировались властью в терминах, ставших привычными технологиями решения этих проблем. При этом не было и нет железной логики неизбежности именно таких технологий мобилизации через синтез власти и собственности.

Геополитическая ситуация, в которой внешняя угроза (реальная или мнимая) постоянно выступает ключевым фактором политики, переплетается с укорененным еще в средневековье отставанием от соперников. Этот объективно 
существующий расклад сил создает основу для альтернативы: либо принять отставание как данность, либо стремиться его преодолеть. Это в свою очередь связано с другой альтернативой: либо быть колонией или периферией другого государства (именно в таком статусе русские земли существовали в эпоху монголо-татарского владычества), либо бороться за статус великой державы, понимаемый, естественно, в терминах соответствующей эпохи. Таким образом, геополитическая ситуация и великодержавный выбор постоянно подталкивали к стратегии догоняющей модернизации, успех которой зависел и зависит от способности государства максимально сосредоточить ресурсы для развития на ключевых направлениях. Но у России никогда не было достаточно сил для завоевания статуса великой державы в области экономики, науки и культуры. Из века в век делался и делается выбор в пользу поддержания этого статуса в первую очередь с помощью военного потенциала, что закономерно требует концентрации экономических ресурсов в руках государства. Такой выбор в пользу военного потенциала не является неизбежным.

\section{Колея авторитаризма}

История российского государства на протяжении веков была историей авторитаризма, мощного ресурса мобилизации сил общества для достижения политических целей (например, военные победы, повышение геополитического статуса державы, рост престижа государства через строительство колоссальных «пирамид», дворцов и спортивных арен). Правда, имели место и исключения - Новгород и Псков, казачья вольница южных степей, земские соборы. Эти национальные политические традиции позволяют утверждать, что демократия в России может опираться не только на логику копирования западных образцов.

С момента завоевания Руси татаро-монголами авторитаризм приобрел заметные «азиатские» оттенки. Тезис о влиянии этого периода на всю дальнейшую судьбу России получил достаточно широкое распространение, и, как писали Ю.С. Пивоваров и А.И. Фурсов, «ордынское иго не просто изменило властные отношения на Руси - оно выковало, вылепило принципиально нового, невиданного доселе в христианском мире субъекта-мутанта» [Пивоваров, Фурсов 1999, с. 188]. О.И. Шкаратан мыслит в том же направлении: ордынское нашествие «... изменило национальный генетический код с европейского на какой-то иной» [Шкаратан, Лексин, Ястребов 2015, с. 29]. Или, как писал В.Б. Пастухов, «... государство навсегда возвысилось над русским обществом и превратилось в главный фактор его культурного развития» [Пастухов 2005, с. 69].

Однако в тени остается вопрос об институциональных скрепах, обеспечивавших такую преемственность многовековой продолжительности, которая дает основание вспоминать средневековье в контексте дискуссий о путях современной России. Категория «генетического кода», вполне достаточная для философии истории, в рамках исторического и социологического исследования превращается в гипотезу, требующую доказательств через выстраивание колоссального эмпирического материала в относительно непрерывную хронику. Иначе говоря, необходимо практически операционализировать эту категорию и применить в конкретно- 
историческом исследовании на основе индуктивной логики. Однако масштабы эмпирического материала неизбежно толкают к обобщениям, которые могут привести к существенному упрощению реальности.

\section{Колея социальной структуры: от бояр к олигархам}

О.И. Шкаратан выдвигает принципиальный тезис о том, что именно ордынская система привела вместе с азиатской деспотией и азиатский (государственный) способ производства, и рыхлую бесклассовую социальную структуру социума без частной собственности, без социальных групп собственников. В ту эпоху и сформировались на столетия вперед качественные отличия российской социетальной системы от европейской [Шкаратан, Лексин, Ястребов 2015, с. 30]. Если опираться на метод исторических аналогий, то так и есть. Однако открытым остается вопрос о реальных механизмах передачи через всю цепь «длительного времени» этой социальной структуры. Категории кода и традиции, не обеспеченные четкой эмпирической операционализацией, отсылают нас к мистике истории. Можно, конечно, нащупать множество частных механизмов преемственности между соседствующими во времени формами, но выстраиваются ли они в один цивилизационный стержень?

О.И. Шкаратан, как и другие исследователи, приверженные цивилизационному подходу, совершенно точно проводят историческую аналогию между раздачей в средние века великими князьями поместий лояльным им боярам и постсоветской олигархической приватизацией [Шкаратан, Ястребов 2016]. Сходство поразительное. В этом же русле рассуждал и В.Э. Шляпентох, убедительно показавший параллели между феодальными и современными российскими институтами [Шляпентох 2008]. Правда, он увидел в России не азиатский способ производства, а феодализм общеевропейского типа и, помимо этого, нашел такую же аналогию и в современных Соединенных Штатах. Под «феодальными» он понимал социальные структуры, независимые от государства и, оставаясь вне системы конкуренции, бросающие вызов и государству, и обществу [Shlapentokh 2011].

Однако объясняет ли эта аналогия, почему Кремль в 1990-е гг. пошел по пути олигархической приватизации? Не думаю. В сходстве форм отнюдь необязательно обнаруживаются причинно-следственные связи. Частично причины следует искать в прошлом, но не в феодальные времена, а в структуре советского хозяйственного комплекса, ядро которого составляли технологически детерминированные крупные производственные объединения. Это советское наследие и предопределило ограниченный набор сценариев для Кремля, вынуждая его принимать решения в ситуации переплетения многих факторов. Неолиберальный поворот руководства последней декады XX в., абсолютизировавший необходимость срочной приватизации, являл собой механическую реакцию на коллапс командной экономики в контексте глобальной моды на неолиберальные рецепты решения проблем. Таким образом, дух времени материализовался с помощью советского технического и организационного наследия. Сохранение крупных комплексов в условиях приватизационного «зуда» (фактор духа времени) диктовалось элементарной экономической логикой: кому можно было передать их в таких условиях? 
Создание публичных корпораций требовало серьезной и длительной подготовки, поэтому передача крупных объектов в руки близким к Кремлю людям, казавшихся верными и надежными, была политически обоснованным шагом в сложившейся ситуации. В результате на смену министрам и генеральным директорам пришли частные собственники - новые бояре, сохранившие технологическую структуру советского хозяйственного комплекса. Как верно констатирует О.И. Шкаратан, «... залоговые аукционы - это в чистом виде осознанные акции по формированию внеконкурентного политикообразующего крупного бизнеса» [Шкаратан, Ястребов 2016, с. 95]. Интересы политической элиты органично совпали с частными устремлениями приближенных к ней «новых русских», направленными на приобретение ценных активов по бросовым ценам. Однако феодальное прошлое здесь ни при чем: налицо не зыбкая национальная традиция, а вполне осязаемая преемственность основных материальных фондов и организационных структур, осмысленная в условиях неолиберальной эйфории, когда советское наследие было втиснуто в капиталистические рамки. Исторические параллели показывают вехи траектории, но не причинно-следственные связи.

\section{Православная колея}

В цивилизационном анализе России существенное место уделяется православию как своего рода стержню, пронизывающему всю историю российского государства. Как пишет О.И. Шкаратан, «... Россию можно уверенно отнести к православной цивилизации, в которой она столетиями занимает лидирующие позиции» [Шкаратан, Лексин, Ястребов 2015, с. 44]. Идея возрождения православной цивилизации высказывалась и С. Хантингтоном [Хантингтон 2003]. Однако быть цивилизационным стержнем означает играть системообразующую роль, т.е. определять формы и смыслы во всех основных сферах жизни на протяжении всей истории, в то же время имеющиеся исторические данные не позволяют перевести эту красивую гипотезу в научно обоснованный вывод. Многие исследователи подвергают сомнению этот тезис, особенно в той части, которая касается постсоветской России [Митрохин 2006; Гудков 2008; Масловский 2012].

Эта тема включает в себя две составляющие: православное мировоззрение как фактор формирования русского менталитета и место в российском обществе православной церкви как социального института. О роли православия в становлении русского менталитета можно говорить много, но трудно прийти к эмпирически фиксируемым аргументам, опирающимся на характеристики массового сознания, а не церковной догматики. Т.Б. Коваль дает глубокий анализ православной идеологии [Шкаратан, Лексин, Ястребов 2015, с. 191-237], но в какой мере она являлась мировоззрением народа?

О проникновении православия в жизнь российского общества и степени его влияния на формирование социальных институтов можно судить только по поведенческим актам и повседневным практикам (см., напр. [Миронов 2009, с. 229-235]). На уровне масс - это посещаемость церкви, которая на всех этапах истории Русской православной церкви (РПЦ), исключая современный, в существенной мере регулировалась внешним социальным контролем. 
Иными словами, эмпирически фиксируется исключительно ритуальная сторона религии, управляемая социальными институтами. В поведении господствующего сословия и государства православное мировоззрение проявлялось еще и в строительстве храмов. Их разрушение в советское время - это тоже ритуальные действия с целью замены православия светской религией марксизма-ленинизма. Уловить влияние православия в политике государство можно только при подключении развитого воображения, поскольку христианские догматы в биографиях царей дальше вербального уровня не прослеживаются, если, разумеется, не использовать в качестве источников жизнеописания в жанре жития.

Однако место РПЦ в системе социальных институтов, ее тесная интеграция с государственной властью - это легко верифицируемые исторические факты, повторяющиеся на протяжении тысячелетней истории, при этом церковь всегда занимала в этом союзе подчиненную роль, выполняя в политической системе идеологические функции. В советское время аппарат КПСС, фактически составлявший ядро государства, в своей идеологической части превратился в своеобразную церковь без бога, и в этом смысле описанная выше колея сохранилась и в советскую эпоху.

Роль РПЦ (а не православного мировоззрения) как ключевого элемента этого пронизывающего всю историю государства стержня усиливается ее имманентным консерватизмом: ни один социальный институт России не охраняет так бережно свои традиции вплоть до мельчайших деталей церковных ритуалов. Возможно, что именно это исключительное следование вековым традициям оказывается особенно важным для современной элиты России фактором обеспечения консервативного поворота в политике.

\section{Ментальная колея народа}

С самого начала применения цивилизационного анализа России и до наших дней исследователи в той или иной мере указывают на ментальности и менталитет как одно из оснований цивилизационной колеи. «Под ментальностями, - констатирует Б.Н. Миронов, - чаще всего имеются в виду стереотипы, автоматизмы и привычки сознания, заложенные воспитанием и культурными традициями, ценностные ориентации, а также значимые представления и взгляды, принадлежащие не отдельным личностям, а той или иной социально-культурной общности, тому или иному сословию, классу или социальной группе. <..> Взятые в совокупности ментальности образуют менталитет - некую систему, нередко противоречивую, которая тем не менее обеспечивает отдельного человека моделью видения мира, способами постановок и решения проблем, с которыми ему приходится сталкиваться, глубинной программой деятельности, правилами и алгоритмами поведения, своего рода инструкциями на все или, по крайней мере, на важные случаи жизни. Русским эквивалентом слова "менталитет" могут служить два почти синонимичных слова - "миропонимание" и “миросозерцание"» [Миронов 2009, с. 205].

При использовании менталитета как фундамента цивилизационной колеи появляются минимум две серьезные проблемы. Во-первых, менталитет формируется прежде всего условиями существования, которые весьма сильно социально диф- 
ференцированы. В силу этого категория менталитета народа предполагает такое значительное количество обобщающих натяжек, что это порождает затруднения в его эмпирическом обосновании. Во-вторых, при всей своей привлекательности категория менталитета в цивилизационном анализе сталкивается с еще большими методологическими проблемами: как найти общий знаменатель даже у одной группы в историческом континууме; что общего у москвича эпохи Ивана Грозного и начала XXI в.? При переходе же к категории народа возникает проблема несопоставимости социальных структур.

Как точно констатирует Н.Г. Розов, «обращение к литературе о национальном менталитете, российском характере, политической культуре (в последние годы весьма объемной и разношерстной) производит крайне удручающее впечатление. Написано очень много, тексты преимущественно весьма идеологизированные, вплоть до кликушеских. С трудом обнаруживаемое из-под толстого слоя штампов (духовность-соборность-коллективизм-всечеловечность) концептуальное содержание почти целиком относится только к статике, практически нет работ об исторической динамике развития национальных менталитетов» [Шкаратан, Лексин, Ястребов 2015, с. 279].

\section{Колея исторической памяти}

Прошлое вторгается в настоящее двояким образом. Во-первых, в форме наследуемых материальных ресурсов (географических и природных условий, памятников материальной культуры). Новые поколения стоят на плечах свершений своих предков. Во-вторых, прошлое входит в настоящее в форме исторической памяти, которая проявляется как поток повествований об ушедших эпохах. Прошлое не действует автоматически, оно опосредуется интересами, знаниями, ценностями повествующих; иначе говоря, взгляд на него осуществляется через пристрастные линзы сегодняшнего дня, конструирующие описания прошлого.

Историческая память, связывающая разные эпохи в единое целое, является одним из типов колеи. Средневековая Русь вторгается в настоящее не объективно, а как постоянно воспроизводимые повествования о ней, прародине современной России. Эти сюжеты подвержены суду времени, составной частью которого становятся современная политика, идеология и массовые настроения. В результате историческая память регулярно меняется: так, разделение России и Украины, приобретшие в последние годы конфликтный характер, привело к процессам дифференциации исторической памяти двух народов. Политики пишут историю более эффективно, чем историки.

Историческая память вырисовывается в разных формах. Во-первых, это историческая мифология, для которой характерны упрощение прошлого до поддающихся усвоению массовым сознанием форм и выполнение мировоззренческой функции. Историческая мифология воспроизводится как стихийно (из уст в уста), так и с помощью социальных институтов (церкви, системы образования, искусства, СМИ, организуемых государством праздничных ритуалов и т.д.). Это очень важная часть колеи, краеугольными камнями которой становятся сакрализованные воспоминания об отдельных событиях прошлого; на них держится миф, поэтому 
подвергать их критической деконструкции опасно. Во-вторых, история как наука, которая стремится к объективности, беспристрастности, опирается на научные методы сбора и верификации данных, построения доказательств. Разумеется, эта наука всегда и везде находится под более или менее сильным общественным давлением, что делает смещение в сторону мифологии и идеологии ее системным отклонением. При этом история остается наукой в той мере, в какой ей удается поддерживать свободу от мифологии (см. подр. [Ильин 2015]).

Таким образом, историческая память - это социальный конструкт, воспроизводимый в конкретно-исторических формах в каждую эпоху. Она выполняет важную функцию формирования исторической колеи народа, пронизывающей целые эпохи. Однако конфигурации этой колеи регулярно изменяются под давлением политики, идеологии, массовых настроений и достижений исторической науки; иными словами, колея - это процесс, регулярно меняющий свое русло. Однако объективное прошлое, выступающее предметом исторической памяти, является одним из ресурсов, формирующих цивилизационный стержень (например, россияне обречены вспоминать об отношения русских княжеств и Золотой Орды, о нашествиях Наполеона и Гитлера).

\section{Выводы}

Цивилизационный анализ и концепции социальной инерции (зависимости от прошлого) направлены на выявление логики взаимосвязи настоящего с ушедшими в историю эпохами, однако при всей общности предмета они существенно различаются. Первый, вытекая из логики философии истории, направлен на дедуктивное упорядочивание фактов по двум линиям: исторических параллелей внутри одной цивилизации и синхронного сравнения с другими цивилизациями. При этом в тени остается выявление причинно-следственных связей между социальными институтами разных эпох российской истории.

Концепции социальной инерции, вырастая из логики экономических исследований, гораздо меньше интересуются построением исторически продолжительных трендов, концентрируя внимание на механизмах обеспечения институциональной преемственности соседних эпох и существующих между ними причинно-следственных отношений.

Интеграция этих двух подходов не может представлять собой их механическое смешение, а предполагает серьезные методологические изыскания. Одним из путей интеграции цивилизационного подхода и концепций социальной инерции является определение ресурсов, оказывающих перманентное влияние на институциональное развитие на протяжении многих эпох. Цивилизационный стержень, пронизывая разные исторические эпохи, демонстрирует многообразие конкретноисторических форм использования одних и тех же ресурсов. Категория колеи не является синонимом траектории. Она фокусирует внимание не столько на описание исторических параллелей в национальной истории, сколько на выявление механизмов обеспечения преемственности между целой серией исторических эпох. Среди этих механизмов ключевую роль играют использованные способы включения ресурсов в обеспечение социальной деятельности. 
Историческая колея России имеет сложную структуру горизонтального и вертикального типов; она прослеживается в виде путаных траекторий развития в самых разных сферах жизни. Всякие попытки придать этой колее логически четкий и стройный характер чреваты сближением с исторической мифологией, для которой характерны упрощающие реальность обобщения, выбор удобных исторических примеров и сильная чувствительность к политике и идеологии конкретного времени, что представляет серьезный вызов цивилизационному анализу как методологии исследования.

\section{Литература}

Бауман 3. (2008) Текучая современность. СПб.: Питер.

Бессонова О.Э. (2006) Раздаточная экономика России. Эволюция через трансформации. М.: РОССПЭН.

Бессонова О.Э. (2015) Рынок и раздаток в российской матрице: от конфронтации к интеграции. М.: РОССПЭН.

Бродель Ф. (1977) История и общественные науки. Историческая длительность // Кон И.С. (ред.) Философия и методология истории. М.: Прогресс. С. 115-142.

Бродель Ф. (1992) Материальная цивилизация, экономика и капитализм, XV-XVIII вв. М.: Прогресс.

Бродель Ф. (2008) Грамматика цивилизаций. М.: Весь мир.

Данилевский Н.Я. (1991) Россия и Европа. М.: Книга.

Ильин В.И. (2015) История как социальный ресурс развития глубинки // Журнал социологии и социальной антропологии. Т. XVIII. № 2 (78). С. 146-162.

Кирдина С.Г. (2000) Институциональные матрицы и развитие России. М.: ТЕИС.

Кордонский С.Г. (2008) Сословная структура постсоветской России. М.: ФОМ.

Масловский М.В. (2012) Цивилизационный анализ в современной исторической социологии и российские политические трансформации // Мир России. Т. 21. № 3. С. 119-132.

Миронов Б.Н. (2003) Социальная история России периода империи (XVIII - начало XX в. В 2 т. СПб: «Дмитрий Буланин».

Миронов Б.Н. (2009) Историческая социология России. Учебное пособие. СПб: Издательский дом С.-Петербургского университета; Интерсоцис.

Нуреев Р.М., Латов Ю.В. (2010) Россия и Европа: эффект колеи (опыт институционального анализа истории экономического развития). Калининград: изд-во РГУ им. И. Канта.

Нуреев Р.М. (2001) Социальные субъекты постсоветской России: история и современность // Мир России. Т. 10. № 3. С. 3-66.

Пастухов В.Б. (2005) Шаг назад, два шага вперед. Русское общество и государство в межкультурном пространстве // ПОЛИС. № 6. С. 66-91.

Пивоваров Ю.С., Фурсов А.И. (1999) Русская система и реформы // Pro et Contra. Т. 4. № 4. С. 188-189.

Полтерович В.М. (1999) Институциональные ловушки и экономические реформы // Экономика и математические методы. Т. 35. № 2. С. 1-37.

Путин В.В. (2007) Выступление президента России Владимира Путина на Мюнхенской конференции по вопросам политики безопасности. 10 февраля 2007 г. // «Известия». 12 февраля 2017 // http://izvestia.ru/news/321595

Розов Н.С. (2011) Колея и перевал. Макросоциологические основания стратегий России в ХХІ веке. М.: РОССПЭН.

Соловьев С.М. (1996) История России с древнейших времен. В 29 томах. Т. 18, кн. Х. М.: Мысль.

Тойнби А.Дж. (1991) Постижение истории. Сборник. М.: Прогресс.

Тэн И. (1907) Происхождение современной Франции. Т.1. СПб.: Изданіе А.С. Суворина. 
Хантингтон С. (2003) Столкновение цивилизаций. М.: АСТ.

Шкаратан О.И. (2004) Российский порядок: вектор перемен. М.: Вита пресс.

Шкаратан О.И., Лексин В.Н., Ястребов Г.А. (ред.) (2015) Россия как цивилизация: материалы к размышлению. М.: Редакция журнала «Мир России».

Шкаратан О.И., Ястребов Г.А. (ред.) (2016) Нова ли новая Россия? М.: Университетская книга.

Шляпентох В.Э. (2011) Социолог Владимир Шляпентох - о «феодальной Америке» // Радио «Свобода». 12 мая $2011 / / \mathrm{http}: / / w w w . s v o b o d a . o r g / a / 25701473 . h t m l$

Shlapentokh V. (2011) Feudal America: Elements of the Middle Ages in Contemporary Society, University Park: Penn State University Press.

\title{
The Structure of Russia's Historical Path Dependency
}

\section{ILYIN*}

*Vladimir Ilyin - Doctor of Science in Sociology, Professor, St. Petersburg State University, Syktyvkar State University; Associated Researcher, Sociological Institute RAS. Address: 7-9, Universitetskaya Guay, Saint-Petersburg, 199034, Russian Federation. E-mail: ivi-2002@yandex.ru

Citation: Ilyin V. (2017) The Structure of Russia's Historical Path Dependency. Mir Rossii, vol. 26, no 4, pp. 30-50 (in Russian). DOI: 10.17323/1811-038X-2017-26-4-30-50

\begin{abstract}
This article deals with a number of topics raised in the two monographs "Russia as a Civilization" and "Is New Russia New?". It clarifies the categorical apparatus which allows the integration of the civilizational approach and path dependency. An important problem with the civilizational approach is rooted in its origin: the approach was first developed within the framework of the philosophy of history, the methodology of which is not sensitive to empirical details. Later the popularity of this approach led to its transmigration into more exact disciplines - history, including economic history, and sociology. However, the shift in the subject field was not supported by the adequate development of a particular scientific methodology. As a result, the question of Russia's place in the system of local civilizations remains more a matter of faith, and none of the contending parties are able to supply arguments that can convince their opponents.

The main drawback of existing civilizational studies is their voluntary treatment of historical data: countries are often contemporaneously compared regardless of the fact that they may be going through different stages of development, analogies are often drawn arbitrarily in order to fit into the deductive logic, and the facts are generally cherry picked to justify chosen theoretical concepts. Not surprisingly, despite its long history, civilizational analysis in Russia still remains more integrated into ideological, rather than scientific discourse. On the other hand, the concept of path dependency, which originated
\end{abstract}


in the economic sciences, is much more accurate and specific, yet precisely for this reason it struggles to explain the dynamics of history over the scale of a thousand years.

In this paper I propose two sets of categories which may be helpful for integrating the civilizational approach and path dependency. The first set of categories pertains to the analysis of the mechanisms of historical continuity within a single civilization: 1) a civilizational core as a set of factors acting throughout a civilization's history; 2) a historical track as a real trajectory in the context of available resources; 3) civilizational traps (often political) as specific developments that lead to irreversible consequences. The second set of categories distinguishes between different domains of historical continuity such as geography, geopolitics, politics, religion, the history of ownership relations and historical memory. I argue that such a categorical grid allows for the proper empirical testing of hypotheses often drawn from civilizational analysis.

Key words: civilization approach, social inertia, path dependency, civilizational core, civilizational track, civilizational trap, social resources, geographical and geopolitical factors, Orthodoxy, mentality, historical memory

\section{References}

Bauman Z. (2008) Tekuchaya sovremennost' [Liquid Modernity], Saint-Peterburg: Piter.

Bessonova O.E. (2015) Rynok i razdatok v rossijskoj matritse: ot konfrontatsii $k$ integratsii [Market and Distribution in the Russian Institutional Matrix: from Confrontation to Integration], Moscow: ROSSPEN.

Bessonova O.E. (2006) Razdatochnaya ekonomika Rossii. Evolyutsiya cherez transformatsii [Russia's Redistributive Economy. Evolution through Transformation], Moscow: ROSSPEN. Brodel F. (1977) Istoriya i obschestvennye nauki. Istoricheskaya dlitel'nost' [Ecrits sur l'histoire]. Filosofiya i metodologiya istorii (ed. Kon I.S.), Moscow: Progress, pp. 115-142.

Brodel F. (1992) Material'naya tsivilizatsiya, ekonomika i kapitalizm, XV-XVIII vv. [Civilisation Matérielle, Economie et Capitalisme, XVe-XVIIIe siècle], Moscow: Progress.

Brodel F. (2008) Grammatika tsivilizatsij [Grammaire des Civilisations], Moscow: Ves' mir. Danilevskij N.Ya (1991) Rossiya i Evropa [Russia and Europe], Moscow: Kniga.

Ilin V.I. (2015) Istoriya kak sotsialnyj resurs razvitiya glubinki [History as the Social Resource of Remote Village Development]. Zhurnal sotsiologii i sotsial'noj antropologii, vol. 18, no 2 (78), pp. 146-162.

Kirdina S.G. (2000) Institutsionalnye matritsy i razvitie Rossii [The Institutional Matrix and Russia's Developpment], Moscow: TEIS.

Kordonskiy S.G. (2008) Soslovnaya struktura postsovetskoj Rossii [Estate Structure of the Post-Soviet Russia], Moscow: FOM.

Maslovskij M.V. (2012) Tsivilizatsionnyj analiz v sovremennoj istoricheskoj sotsiologii i rossijskie politicheskie transformatsii [Civilisational Analysis in Contemporary Historical Sociology and Russian Political Transformation]. Mir Rossii, vol. 21, no 3, pp. 119-132.

Mironov B.N. (2003) Sotsial'naya istoriya Rossii perioda imperii (XVIII - nachalo XX v.) [Social History of Imperial Russia (18-20-th centuries)], Saint-Peterburg: «Dmitriy Bulanin».

Mironov B.N. (2009) Istoricheskaya sotsiologiya Rossii [Historical Sociology of Russia], SaintPeterburg: Izdatelskij dom S.-Peterburgskogo universiteta; Intersotsis.

Nureev R.M., Latov Yu.V. (2010) Rossiya i Evropa: effekt kolei (opyt institutsional'nogo analiza istorii ekonomicheskogo razvitiya) [Russia in Europe: The Effect of Path Dependency (an Institutional Analysis of Economical Development], Kaliningrad: RGU. 
Nureev R.M. (2001) Sotsialnyie sub'ekty postsovetskoj Rossii: istoriya i sovremennost' [Social Agents in Post-Soviet Russia: Past and Present]. Mir Rossii, vol. 10, no 3, pp. 3-66.

Pastukhov V.B. (2005) Shag nazad, dva shaga vpered. Russkoe obshchestvo i gosudarstvo v mezhkul'turnom prostranstve [One Step Backward, Two Steps Forward. Russain Society and the State in the Transcultural Space]. POLIS, no 6, pp. 66-91.

Pivovarov Yu., Fursov A. (1999) Russkaya sistema i reformy [The Russian System and Reforms]. Pro et Contra, vol. 4, pp. 188-189.

Polterovich V.M. (1999) Institutsionalnye lovushki i ekonomicheskie reformy [Institutional Traps and Economic Reforms]. Ekonomika i matematicheskie metody, vol. 35, no 2, pp. 1-37.

Putin V.V. (2007) Vystuplenie prezidenta Rossii Vladimira Putina na Myunkhenskoj konferentsii po voprosam politiki bezopasnosti 10 fevralya 2007 goda [President Putin's Speech at the Munich Conference on Security Politics, Feb. 10, 2007]. Izvestiya, 12 February 2017. Available at: http://izvestia.ru/news/321595, accessed 31 August 2017.

Rozov N.S. (2011) Koleya i pereval: makrosotsiologicheskie osnovaniya strategij Rossii $v$ $X X I$ veke [The Track and the Pass: Macrosociological Foundations of Russia's Strategies in the 21st Century], Moscow: ROSSPEN.

Solov'ev S.M. (1996) Istoriya Rossii s drevnejshikh vremen [Russian History from Ancient Times]. In 29 vols, vol. 18, b. 10, Moscow: Mysl'.

Toynbee A.J. (1991) Postizhenie istorii [A Study of History], Moscow: Progress.

Taine H (1907) Proiskhozhdenie sovremennoj Frantsii [Les Origines de la France Contemporaine]. Vol. 1, Saint-Peterburg: IzdanIe A.S. Suvorina.

Huntington S. (2003) Stolknovenie tsivilizatsij [The Clash of Civilizations], Moscow: AST.

Shkaratan O.I. (2004) Rossijkij poryadok: vektor peremen [The Russian Order: Vector of Changes], Moscow: Vita press.

Shkaratan O.I., Leksin V.N., Yastrebov G.A. (eds.) (2015) Rossiya kak tsivilizatsiya: materialy $k$ razmyishleniyu [Russia as a Civilization: Readings for Reflections], Moscow: Redaktsiya zhurnala «Mir Rossii».

Shkaratan O.I., Yastrebov G.A. (eds.) (2016) Nova li novaya Rossiya [Is New Russia New], Moscow: Universitetskaya kniga.

Shlyapentoh V.E. (2011) Sotsiolog Vladimir Shlyapentoh - o «feodal'noj Amerike» [Sociologist Vladimir Shlapentokh on 'Feudal America']. Radio "Svoboda”. 12 May 2011. Available at: http://www.svoboda.org/a/25701473.html, accessed 31 August 2017.

Shlapentokh V. (2011) Feudal America: Elements of the Middle Ages in Contemporary Society, University Park: Penn State University Press. 